\title{
An Overview of the Important Points of Talent Selection in Sports
}

\author{
Surhat Muniroglu* and Erdem Subak \\ Faculty of Sport Sciences, Ankara University, Turkey \\ *Corresponding author: Surhat Muniroglu, Faculty of Sport Sciences, Ankara University, Turkey
}

Submission: 㭗 May 22, 2018; Published: 監June 11, 2018

\begin{abstract}
Talent selection is the most important phase to train elite athletes for future. In the talent selection stages, there are many important criteria's have shown in the literature. The age is an important criterion. Besides, physical fitness, anthropometric data's have used to the testing athletes for talent selection. On the other hand, the cognitive, perceptual and motor skills are also important factors to determine talented individuals. Researchers have conducted many tests for talent selection also include genetic testing nowadays. This review summarizes the most important criteria's and the most commonly used tests roughly.
\end{abstract}

Keywords: Talent selection; Young athletes; Sports

\section{Introduction}

The main goal in selecting a talent is to train the athlete to the highest level in order to be successful in a sport branch. Interaction of genetic resources such as race, gender, genetic background, intelligence, locomotor, neuromuscular, anatomical structure, psychological state could be the determinants of future performance [1]. A talented athlete is known as a sportsman who has a wide variety of functional repertoire and who can quickly and accurately use these movements in different situations, creating Age

Table 1: The ages of starting special sports training.

\begin{tabular}{|c|c|c|c|c|c|c|c|c|c|}
\hline Age & 7 & 8 & 9 & 10 & 11 & 12 & 13 & 14 & 15 \\
\hline $\begin{array}{l}\text { Sports } \\
\text { Branch }\end{array}$ & $\begin{array}{l}\text { Gymnastics } \\
\text { Aerobic Diving }\end{array}$ & $\begin{array}{c}\text { Tennis } \\
\text { Table } \\
\text { Tennis } \\
\text { Squash }\end{array}$ & Swimming & $\begin{array}{c}\text { Football } \\
\text { Basketball } \\
\text { Volleyball } \\
\text { Handball } \\
\text { Hockey } \\
\text { Badminton } \\
\text { Rugby }\end{array}$ & $\begin{array}{l}\text { Athletics } \\
\text { Cycling } \\
\text { Archery }\end{array}$ & Fencing & $\begin{array}{c}\text { Boxing } \\
\text { Wrestling } \\
\text { Judo }\end{array}$ & $\begin{array}{l}\text { Skiing } \\
\text { Canoe } \\
\text { Rowing }\end{array}$ & $\begin{array}{c}\text { Horse Riding } \\
\text { Pentathlon } \\
\text { Weight } \\
\text { Lifting }\end{array}$ \\
\hline
\end{tabular}

The researches revealed that the sport should be started in childhood in order to achieve the expected success [3]. It is important for talented individuals to be pioneered at an early age in order to be selected, monitored and brought to the top of their mastery. The motor capacity, psychological capacity and biometric- appropriate combinations, and quickly learning and applying new movement patterns and combinations [2]. Genetics, socio-cultural structure, economics and education are factors that are effective in determining talent. In addition, individual, environmental and luck factors are among the determinants of talent. The aim of this review is to bring together the most general information about talent selection on the football, the criteria's used in the selection of talents, the features in the foreground and the frequently used tests. anthropometric properties required for yield are valid for all sports, whichever is more dominant, may be different for each sport [4,5]. Bompa et al. [4] indicates that, talent screening and selection work is proper for 6-12 age group. The ages at which to start training according to the branches are shown in Table 1 [2]. Biological aging 
is a factor that affects growth, performance and physical fitness [6]. Changes in the date of birth of the same year are defined as relative age differences $[7,8]$. It is a very important issue of sport science that children and youngsters are directed to branches in the most efficient way. For this reason, it is important to direct the children to the sports branch where they can be successful at the earliest possible age. Early detection of the potential performance of the sport will provide the basis for the athlete to direct the correct sport and achieve optimum performance.

\section{Physical Fitness and Anthropometric Data's}

As in all sport branches, anthropometric features and physical fitness are also important elements for football. In the process of talent selection and orientation, the anthropometric features and abilities of the individual are two important factors that are jointly assessed for correct orientation and performance estimation. For this reason, anthropometric measurements are made at each stage of the process [9]. Only the length and body weight measurements are made since a wider base scan is performed at the base selection stage than the other stages. According to these measurements, the body compositions of the children are determined and their physical development and fitness status are determined by comparing according to the percentile tables $[4,10]$. In line with this information, children's education planning has done. The anthropometric characteristics of the athletes during the pre-selection phase are a very important factor to consider in their work towards sport. In this phase, in addition to the general measurements made during the basic selection stage, children are tried to determine the most suitable sports branches by determining extremities and bone lengths, body compositions, body fat ratio, lean body mass and somato type [7,11,12]. In the final selection phase, the anthropometric characteristics of the athletes should be determined using advanced techniques and technological equipment. Measurements and calculations to measure body circumference and diameter, body composition and somatotype to be made at this stage will provide important data for evaluating the development and performance level of elite athlete candidates $[2,4,13]$.

\section{Skills}

There are basically three types of skills in sport: Cognitive skills, perceptual skills and motor skills [2]. The cognitive skill includes mental and intellectual skills of the athletes. Cognitive skills are essential for the athlete's perception, effective decision making and problem solving. Perceptual skills are planning to formulate the motor skills according to the current situation by interpreting what they have learned to perform. For example, a footballer takes the correct position to control the ball taking into account the speed of the ball towards him and adjusts the severity of the first contact. And the researchers have divided the basic motor skills into three groups according to their functional characteristics. These are the skills that require balance skills (static or dynamic balance), displacement skills (such as running, jumping, and galp) and object control (such as kicking the ball, throwing ball, throwing and holding) $[14,15]$. On the other hand, there are other very important skills that sports require. The conditional skills (Strength, endurance, speed etc.), coordinative skills (Balance, anticipation, reaction, rhytm etc.) and both conditional and coordinative skills (flexibility and mobility) are another abilities required to be found in talented athletes [2]. Testing all these abilities is important in talent selection.

\section{Talent Selection and Direction Stages}

According to the talent selection and guidance models developed by sports scientists, Hare's model has two stages (1982), Gimbel (1976) and Jones \& Watson's model has four stages (1977) and Bar-Or's model has five stages [2,16]. However, Bompa's model (1985) includes three stages was widely accepted in the sporting world. Compared to other models, the most striking aspect of Bompa's three-stage talent model is that the work planned in the first phase is directed at children aged 3-8 years [4,17]. Bompa's model has divided the talent selection and orientation process into three phases: basic selection, pre-selection and final selection. In the basic selection phase, measurements and comparisons are made to determine general health screening, anthropometric and motoric characteristics of children between 4 and 8 years of age. In this phase, general information and health checks, demographic information is provided. In addition, anthropometric measurements are made, motor skills are determined and basic sports training is provided. In the pre-selection phase, health checks are done again. Then, training adaptation studies, age calculations, identification of psychological professions, skill tests are provided [2,4,17]. In the final selection phase, data on the development and performance levels of athletes, new measurements, skills and laboratory tests can be done to confirm fitness for sports. According to the evaluation results, skilled athletes are directed to the sports high school or camp centres where full-time academic and sport training is given $[4,13]$.

\section{Tests for Talent Selection}

Today, there are many test batteries that are widely used around the world to determine motor skills and physical fitness levels in children and young people. Some of the most used tests are; KrausWeber Minimal Fitness Test, Presidental Physical Fitness Test, Youth Fitness Test, Monibota Physical Fitness Performance Test, National Children and Youth Fitness Study Tests, Crysler Fund Fit Youth Today Program, Fitness gram System, The Allgemeine Sport Motorisher Test and Euro fit Tests [18-24].

Among these tests, the Euro fit test is one of the most frequently used test in researches [25-29]. The Euro fit tests include skin fold thickness measurements, flamingo balance test, plate tapping, sit-and-reach, standing board jump, handgrip test, sit-ups in 30 seconds, bent arm hang, $10 \times 5$ meters shuttle run and 20 meters endurance shuttle run (bleep test) [2].

\section{Genetic Tests}


Research shows that $66 \%$ of sportive performance is related to genetics. The remainder is related to training, nutrition, equipment, motivation, sleep and non-genetic factors [30-32]. Sport genetics is accepted as a new science that examines the genetic organization and functioning of elite athletes. At present more than 120 genetic associations with athletic performance have been shown [30].

Silventionen et al. [33] showed the height, which is critical in most sport branches, is $80 \%$ heritable. Researches showed that elite athletes have genetic differences from sedentary individuals. However, genetic differences between elite endurance athletes and elite force athletes have also been identified. The ratio of the type of muscle fibril showing which spores are predisposed is also associated with the individual's genetic differences [30,34,35]. Researchers think that genetic testing could give important information to an individual even before the start of the sport. In this context, genetic testing is shown as an alternative method of informing the researchers about the type of sport that the individual will be prone to during the talent selection phase [35-40].

\section{Conclusion}

The choice of talent is the most important step to cultivate elite athletes. As well as the selection of talented athletes, how they are trained is also important. At this point, the coaches and instructors have significant duties. Future research should also include topics on how to train selected talents.

\section{References}

1. Epstein D (2014) The sports gene: Inside the science of extraordinary athletic performance: Penguin.

2. Muniroglu S, Ozmen G (2017) Sporda Yetenek Seçimi ve Yönlendirme. Akademisyen Kitabevi, Ankara, Turkey.

3. Mengütay S (1999) Okul öncesi ve ilkokullarda hareket gelișimi ve spor: TUTIBAY.

4. Bompa TO, Buzzichelli C (2018) Periodization: theory and methodology of training: Human kinetics, USA

5. Kunst G, Florescu C (1971) The main factors for performance in wrestling. National Sports Council, Bucharest, Romania.

6. Malina RM, Bouchard C, Bar-Or O (2004) Growth, maturation, and physical activity: Human kinetics, USA

7. Musch J, Grondin S (2001) Unequal competition as an impediment to personal development: A review of the relative age effect in sport. Developmental review 21(2): 147-167.

8. Wattie N, Cobley S, Baker J (2008) Towards a unified understanding relative age effects. J Sports Sci 26(13): 1403-1409.

9. Anshel MH, Lidor R (2012) Talent detection programs in sport: The questionable use of psychological measures. Journal of Sport Behavior 35(3): 239 .

10. Bloom BS, Sosniak LA (1985) Developing talent in young people.

11. Jurimae T, Jurimae J (2001) Growth, physical activity, and motor development in prepubertal children: CRC Press, USA.

12. Kovár $\mathrm{R}$ (1981) Human variation in motor abilities and its genetic analysis: Charles University, Faculty of physical education and sport.

13. Regnier G, Salmela J, Russell S (1993) Talent detection and development in sport.

14. Gallahue DL, Ozmun JC, Goodway J (2006) Understanding motor development: Infants, children, adolescents, adults: Boston, USA

15. Payne VG, Isaacs LD (2017) Human motor development: A lifespan approach, Routledge, USA.

16. Vaeyens R, Lenoi M, Williams AM, Philippaerts RM (2008) Talent identification and development programmes in sport. Sports Med 38(9): 703-714.

17. Bompa TO (2000) Total training for young champions: Human Kinetics, USA

18. Adam C, Klissouras V, Ravazzolo M, Renson R, Tuxworth W (1988) EUROFIT: European test of physical fitness. Council of Europe, Committee for the development of sport, Rome, Italy.

19. Bös K, Wohlmann R (1987) Allgemeiner Sportmotorischer Test (AST 6-11) zur Diagnose der konditionellen und koordinativen Leistungsfähigkeit. Lehrhilfen für den Sportunterricht 36(10): 145-156.

20. Kraus H, Hirschland R (1954) Minimum muscular fitness tests in school children. Research Quarterly. American Association for Health. Physical Education and Recreation 25(2): 178-188.

21. Manitoba Department of E (1977) Manitoba physical fitness performance test manual and fitness objectives. In: Department of Education Manitoba, USA

22. Meredith MD, Welk G (2003) Fitness gram: Test administration manual: Human Kinetics Publishers, USA.

23. Morrow JR, Mood D, Disch J, Kang M (2015) Measurement and Evaluation in Human Performance, Human Kinetics, USA.

24. Ross JG (1985) National Children and Youth Fitness Study. Parks and Recreation 20(1): 80-87.

25. Gill JMR, Hawari NSA, Maxwell DJ, Louden D, Mourselas N, et al. (2018) Validation of a novel device to measure and provide feedback on sedentary behavior. Med Sci Sports Exerc 50(3): 525-532.

26. Gulías-González R, Sánchez-López M, Olivas-Bravo Á, Solera-Martínez M, Martínez-Vizcaíno V (2014) Physical fitness in Spanish schoolchildren aged 6-12 years: reference values of the battery EUROFIT and associated cardiovascular risk. J Sch Health 84(10): 625-635.

27. Ranson R, Stratton G, Taylor SR (2015) Digit ratio (2D: 4D) and physical fitness (Eurofit test battery) in school children. Early human development 91(5): 327-331.

28. van Nassau F, van der Ploeg HP, Abrahamsen F, Andersen E, Anderson AS et al. (2016) Study protocol of European Fans in Training (EuroFIT): a four-country randomised controlled trial of a lifestyle program for men delivered in elite football clubs. BMC public health 16(1): 598

29. Vancampfort D, Sienaert P, Wyckaert S, De Hert M, Stubbs B, et al. (2015) Test-retest reliability, feasibility and clinical correlates of the Eurofit test battery in people with bipolar disorder. Psychiatry Res 228(3): 620-625.

30. Ahmetov II, Fedotovskaya ON (2015) Current progress in sports genomics. Advances in clinical chemistry 70: 247-314

31. Ahmetov II, Gavrilov DN, Astratenkova IV, Druzhevskaya AM, Malinin AV, et al. (2013) The association of ACE, ACTN3 and PPARA gene variants with strength phenotypes in middle school-age children. J Physiol Sci 63(1): 79-85.

32. Lopez-Leon S, Tuvblad C, Forero DA (2016) Sports genetics: the PPARA gene and athletes' high ability in endurance sports. A systematic review and meta-analysis. Biology of sport 33(1): 3

33. Silventoinen K, Magnusson PKE, Tynelius P, Kaprio J, Rasmussen F (2008) Heritability of body size and muscle strength in young adulthood: a study of one million Swedish men. Genet Epidemiol 32(4): 341-349. 
34. Ahmetov II, Druzhevskaya AM, Lyubaeva EV, Popov DV, Vinogradova OL, et al. (2011) The dependence of preferred competitive racing distance muscle fibre type composition and ACTN3 genotype in speed skaters. Exp Physiol 96(12): 1302-1310.

35. Guth LM, Roth SM (2013) Genetic influence on athletic performance. Curr Opin Pediatr 25(6): 653-658.

36. Jamshidi Y, Montgomery HE, Hense HW, Myerson SG, Torra IP, et al (2002) Peroxisome proliferator-activated receptor $\alpha$ gene regulates left ventricular growth in response to exercise and hypertension. Circulation 105(8): 950-955
37. Gagné F (2004) Transforming gifts into talents: The DMGT as developmental theory. High ability studies 15(2): 119-147.

38. Katsnelson A (2011) Gene tests for brain injury still far from the football field. Nature Publishing Group, UK.

39. Roth SM (2012) Critical overview of applications of genetic testing in sport talent identification. Recent Pat DNA Gene Seq 6(3): 247-255.

40. Subak E, Özdemir FNŞ, Muniroglu RS (2017) Sporcuların başarisinda genetik faktörlerin önemi. Spormetre 3(15): 109-118.

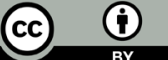

Creative Commons Attribution 4.0 International License

For possible submissions Click Here

\section{Submit Article}

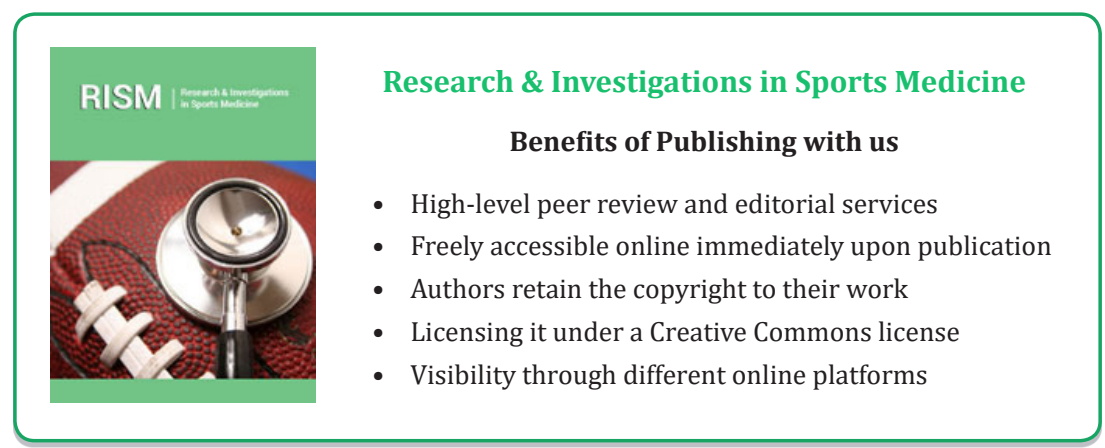

